\title{
Bank Financing for SMEs: Evidence Across Countries and Bank Ownership Types
}

\author{
Thorsten Beck • Asli Demirgüç-Kunt • \\ María Soledad Martínez Pería
}

Received: 18 November 2008 /Revised: 14 April 2010 / Accepted: 21 May 2010 /

Published online: 1 July 2010

(C) The Author(s) 2010. This article is published with open access at Springerlink.com

\begin{abstract}
Using data for 91 large banks from 45 countries, this paper finds that foreign, domestic private, and government-owned banks use different lending technologies and organizational structures for SME financing. The extent, type, and pricing of SME loans, however, is not strongly correlated with lending technologies and organizational structures, suggesting that SME financing need not be based only on "relationship lending". Consistent with these results, we find few significant differences in the extent, type, and pricing of SME loans across bank types. Instead, we find significant differences across developed and developing countries, driven by differences in the institutional and legal environment.
\end{abstract}

Keywords Bank financing - Small and medium-sized enterprises · Small and medium-size enterprises $\cdot$ Business environment $\cdot$ Financing constraints $\cdot$ Lending techniques

JEL G21 · G30

\section{Introduction}

The financing of small and medium-sized enterprises (SMEs) has been a subject of great interest both to policymakers and researchers because of the significance of SMEs in private sectors around the world and the perception that these firms are financially constrained. Data collected by Ayyagari et al. (2007) for 76 developed and developing countries indicate that, on average, SMEs account for close to $60 \%$ of manufacturing employment. More importantly, a number of studies using firm-level survey data have

T. Beck $(\bowtie)$

CentER, Department of Economics, Tilburg University, P.O.Box 90153,

5000 LE Tilburg, Netherlands

e-mail: T.Beck@uvt.nl.Address

A. Demirgüç-Kunt • M. S. M. Pería

World Bank, Washington, DC, USA 
shown that SMEs not only perceive access to finance and the cost of credit to be greater obstacles than large firms, but these factors constrain SMEs (i.e., affect their performance) more than large firms (Schiffer and Weder 2001; IADB 2004; Beck et al. 2005, 2006).

In recent years a debate has emerged regarding the nature of bank financing for SMEs. Until recently, the conventional wisdom regarding SME finance was that small and domestic private banks are more likely to finance SMEs because they are better suited to engage in "relationship lending", a type of financing based primarily on "soft" information gathered by the loan officer through continuous, personalized, direct contacts with SMEs, their owners and managers, and the local community in which they operate (see Berger et al. 1995, 2001; Keeton 1995; Berger and Udell 1996; and Strahan and Weston 1996; Mian 2006; and Sengupta 2007). Also, studies such as Stein (2002), Mian (2006), Canales and Nanda (2008), and Liberti and Mian (2009) have argued that more centralized and hierarchical organizational structures can have a negative impact on lending to opaque borrowers, such as SMEs. However, some recent studies (see Berger and Udell 2006; Berger et al. 2007; and de la Torre et al. 2010) have begun to dispute this conventional wisdom and propose a new paradigm for bank SME finance, arguing that large and foreign banks can be as effective in SME lending through arms-length lending technologies (e.g., asset-based lending, factoring, leasing, fixed-asset lending, credit scoring, etc.) and centralized organizational structures instead of relationship lending.

This paper tries to inform this recent debate using newly gathered data for 91 large banks from 45 countries. Specifically, to our knowledge, this is the first study to rigorously test a number of hypotheses that emerge from the literature proposing a new paradigm for SME finance. ${ }^{1}$ First, we examine whether different bank ownership types use different lending technologies and organizational structures in lending to SMEs. In particular, we examine whether foreign banks are more likely than domestic private banks to use arms-length lending technologies based on hard information and centralized organizational structures. Second, we investigate whether arms-length lending technologies and centralized organizations structures are just as suitable for SME lending as relationship lending. Third, we test whether, although foreign banks make greater use of arms-length lending technologies and centralized organizational structures, they do not tend to specialize less heavily in SME finance or make SME loans on less favorable terms than domestic private banks. Finally, we analyze whether the institutional and legal environment of the country affects the extent, type, and pricing of SME loans.

Our paper focuses on banks as opposed to other financial institutions because studies have shown that banks are the main source of external finance for SMEs across countries (see Beck et al. 2008a). Furthermore, we concentrate on large banks due to their systemic importance and their significance as potential SME financiers. ${ }^{2}$ However, there are undoubtedly some selection biases that might arise from restricting our sample to large banks. First, we might be leaving out some domestic niche banks (for example cooperative banks) that are especially focused on SME lending. Second, to the extent that large banks around the world are more likely to be similar to each other in terms of lending technologies and organizational structures, and given that most foreign banks in developing countries tend to be large,

\footnotetext{
${ }^{1}$ A number of papers by staff at the World Bank have looked at the SME lending practices of banks in developing countries, but the analysis in those papers is purely descriptive (see World Bank 2007a; b; De la Torre et al. 2010; Stephanou and Rodriguez 2008).

${ }^{2}$ Large banks are also the ones with the most extensive branch networks and, hence, the ones most accessible to SMEs, at least in terms of location.
} 
focusing only on large banks might downplay potential differences in lending technologies and organizational structures across bank ownership types.

Our results offer empirical support for the hypotheses posed by the recent literature advocating a new paradigm in SME finance. We find that banks of different ownership types apply different lending technologies and organizational structures in lending to SMEs. In particular, foreign banks grant a higher share of collateralized loans, are less likely to rate soft information as important in evaluating loans, and are also less likely to decentralize loan approval and risk management decisions. However, we find few significant correlations between lending technologies and organizational structures, on the one hand, and the extent, type and pricing of SME lending, on the other hand. Consistent with these findings, we find few differences in the extent, type, and pricing of SME loans across foreign and domestic private banks. Instead, we find significant differences across banks in developed and developing countries that appear to be driven by differences in the institutional and legal environment. In particular, banks in developing countries provide a lower share of investment loans and charge higher fees to SMEs than those in developed countries. Finally, banks in developing countries also tend to charge higher interest rates on small firm loans.

The rest of the paper is organized as follows. Section 2 describes the survey used to gather our data. Section 3 investigates differences in lending technologies and organizational structures across bank ownership types. Section 4 examines the correlation between lending technologies and organizational structures, on the one hand, and the extent, type, and pricing of bank financing to SMEs, on the other hand. Section 5 explores differences in the extent, type, and pricing of bank financing to SMEs across banks of different ownership. In particular, this section tests whether foreign banks tend to specialize less heavily in SME finance or make SME loans on less favorable terms than domestic private banks. Also, this section examines differences in SME lending across countries and tries to relate these differences to measures of the institutional and legal environment. Finally, Section 6 concludes.

\section{The survey}

To gather information on bank financing to SMEs around the world, we designed a survey with 56 questions with the aim of (1) documenting banks' perceptions regarding the SME segment, (2) understanding banks' business models (in particular, lending technologies and organizational structures) used to serve SMEs, and (3) quantifying the extent, type, and pricing of bank financing to SMEs. ${ }^{3}$

Using data from Bankscope, we identified the five largest commercial banks in terms of assets in close to 80 countries around the world and invited them to respond to our survey throughout 2007. Table 1 lists the countries that responded to our survey, shows the number of banks that participated from each country, along with the banks' combined market share. In total, we obtained responses from 91 banks in 45 countries. On average, the banks that responded account for $32 \%$ of banking system loans in each country. The loan market share exceeds $30 \%$ for 24 countries. For 25 countries, we were able to get a response from the largest bank in the system. We obtained multiple bank responses for 30 countries: for 4

\footnotetext{
${ }^{3}$ The working paper version of this paper (see Beck et al. 2008b) provides more information regarding banks' perceptions of the SME segment, discusses the perceived drivers and obstacles to SME finance, and examines banks' views of government programs to support SME finance.
} 
countries we got 4 banks to respond in each country, for 8 countries we received responses from 3 banks, and for 18 countries we obtained 2 bank responses. Only one bank responded in 15 countries.

Among the 45 countries in our sample, 38 are developing and the remaining 7 are developed. Our dataset covers 14 countries in Eastern Europe and Central Asia, 9 in Latin America and the Caribbean, 8 in Sub-Saharan Africa, 4 in South Asia, 2 in the Middle East and North Africa and 1 in East Asia. All 7 developed countries are in Western Europe.

As summarized in Table 2, our survey includes 11 banks operating in developed countries and 80 banks operating in developing countries. In terms of bank ownership types, our sample includes 17 government-owned banks (one operating in a developed economy and the remaining 16 in developing countries), 32 domestic private banks (6 in developed countries and 26 in developing countries) and 42 foreign-owned banks (4 in developed countries and 38 in developing countries).

Rather than giving banks a predetermined size classification of firms, the survey asked banks to provide their own definition of small and medium-sized firms. In particular, banks were asked to provide a range in terms of sales, assets, or employees. Most banks $(85 \%)$ define SMEs in terms of annual sales. In particular, on average, banks define small firms as those with annual sales between 200,000 and 4 million U.S. dollars and medium-sized firms as those with sales between 2 and 16 million dollars. ${ }^{4}$ The average midpoint of the range for small firms is 2 million dollars and for medium-sized firms is 9 million dollars.

The definition of an SME is not very different across banks. Figures $1 \mathrm{a}$ and $\mathrm{b}$ plot the cumulative frequency of the midpoint for the range provided as definition for small and medium-sized firms, respectively. Close to $70 \%$ of banks define small and medium-sized firms as those with sales of less than 2.5 and 10 million dollars, respectively. Furthermore, the definition provided by banks is remarkably similar to the average annual sales reported by small and medium-sized firms in recent enterprise surveys conducted by The World Bank for the countries in our sample: 1.8 million dollars in the case of small firms (defined in the enterprise surveys as those with less than 20 employees) and 14.5 million dollars in the case of medium-sized firms (those with 20 to 99 employees). Since the enterprise survey samples are constructed to be representative of the universe of firms in each country, this suggests that banks are defining SMEs in a way that is consistent with the actual size distribution of firms. In other words, these statistics reduce the concern that banks' definition of SMEs refers to firms that are substantially larger than those operating in the countries in our sample.

\section{Lending technologies and organizational structures across banks}

Do banks of different ownership type adopt different lending technologies and organizational structures to lend to SMEs, once we control for country differences? In particular, is it the case that, as some studies suggest, foreign banks are more likely to apply arms-length lending technologies and centralized organization structures to SME lending (e.g., Berger et al. 2001; Mian 2006). In this first result section, we test for differences in lending technologies and organizational structures across domestic private, government-

\footnotetext{
${ }^{4}$ Banks were asked to provide a range for their definition of small and medium-sized firms. The averages mentioned here refer to the lower and upper limits of the range provided by each bank.
} 
Table 1 Characteristics of survey respondents. Table shows the countries in our sample, the number of banks that responded from each country (including whether the largest bank has participated in the survey), and the market share of respondents relative to total loans

Country No. of bank respondents Has the largest bank responded? Market share covered (\% of ( $\%$ of loans to total system loans)

\begin{tabular}{|c|c|c|c|}
\hline Albania & 3 & Yes & $59 \%$ \\
\hline Armenia & 3 & Yes & $35 \%$ \\
\hline Austria & 1 & & $1 \%$ \\
\hline Belarus & 1 & Yes & $48 \%$ \\
\hline Belgium & 1 & & $10 \%$ \\
\hline Bosnia & 2 & Yes & $38 \%$ \\
\hline Brazil & 1 & & $9 \%$ \\
\hline Bulgaria & 2 & Yes & $32 \%$ \\
\hline Chile & 1 & & $19 \%$ \\
\hline Colombia & 3 & Yes & $48 \%$ \\
\hline Costa Rica & 2 & Yes & $31 \%$ \\
\hline Croatia & 2 & & $22 \%$ \\
\hline Ecuador & 1 & Yes & $38 \%$ \\
\hline El Salvador & 1 & & $26 \%$ \\
\hline Ethiopia & 1 & & $16 \%$ \\
\hline Finland & 1 & Yes & $38 \%$ \\
\hline Georgia & 3 & & $47 \%$ \\
\hline Greece & 2 & Yes & $33 \%$ \\
\hline Honduras & 2 & & $29 \%$ \\
\hline Hungary & 2 & Yes & $35 \%$ \\
\hline India & 4 & Yes & $41 \%$ \\
\hline Indonesia & 2 & & $20 \%$ \\
\hline Jordan & 1 & & $6 \%$ \\
\hline Kenya & 2 & Yes & $27 \%$ \\
\hline Lebanon & 3 & Yes & $37 \%$ \\
\hline Lithuania & 3 & & $48 \%$ \\
\hline Malawi & 2 & Yes & $65 \%$ \\
\hline Malta & 3 & Yes & $71 \%$ \\
\hline Mexico & 2 & Yes & $23 \%$ \\
\hline Moldova & 2 & & $35 \%$ \\
\hline Nepal & 1 & & $8 \%$ \\
\hline Pakistan & 1 & Yes & $14 \%$ \\
\hline Poland & 1 & & $8 \%$ \\
\hline Sierra Leone & 2 & & $21 \%$ \\
\hline Slovakia & 2 & Yes & $40 \%$ \\
\hline Slovenia & 4 & Yes & $61 \%$ \\
\hline South Africa & 2 & Yes & $11 \%$ \\
\hline Sri Lanka & 4 & Yes & $69 \%$ \\
\hline Swaziland & 1 & & $35 \%$ \\
\hline Sweden & 1 & & $27 \%$ \\
\hline Switzerland & 2 & Yes & $40 \%$ \\
\hline
\end{tabular}


Table 1 (continued)

\begin{tabular}{lccc} 
Country & No. of bank respondents & Has the largest bank responded? & $\begin{array}{l}\text { Market share covered (\% of } \\
\text { (\% of loans to total system loans) }\end{array}$ \\
\hline Turkey & 3 & Yes & $24 \%$ \\
Uruguay & 2 & Yes & $46 \%$ \\
Zambia & 2 & & $28 \%$ \\
Zimbabwe & 4 & & $25 \%$ \\
\hline
\end{tabular}

owned, and foreign-owned banks. When it comes to government-owned banks, to our knowledge, the existing literature offers no evidence or predictions as to the lending technologies or organizational structures used by these banks to lend to SMEs. ${ }^{5}$ Nonetheless, we feel it is interesting to use our data to explore whether any patterns exist.

In order to test for differences in lending technologies and organizational structures across banks types, we estimate Eq. 1:

$$
\mathrm{Z}_{i}=\alpha_{0}+\alpha_{1} \text { Foreign }_{i}+\alpha_{2} \text { Domestic Private }_{i+} \alpha_{3} \text { Dev }_{i}+e_{i}
$$

where $\mathrm{i}$ refers to the bank and $\mathrm{Z}$ captures aspects of the lending technologies and the organizational structures used in SME lending. In particular, we consider five separate dimensions: Use of scoring is a variable that takes the value of 1 if scoring is used by the bank in making lending decisions and 0 otherwise. Importance of soft information is a dummy that equals 1 if the bank rates "soft" information (captured by firm owner characteristics) among the top two factors that the bank considers in making loan decisions and 0 otherwise. ${ }^{6}$ Share of SME loans secured is the percentage of SME loans that is collateralized. Decentralization of loan approval is a variable that takes the value of 1 if lending decisions are made only or primarily at bank branches and 0 otherwise. Similarly, Decentralization of risk management is a variable that takes the value 1 if all risk management decisions are made only or primarily at bank branches and 0 otherwise. Foreign takes the value of 1 if the bank is foreign owned; Domestic Private is 1 if the bank is domestic privately-owned; Dev is 1 if the bank operates in a developing country. Because the use of scoring, the importance of soft information, and the extent of decentralization are binary response variables, we estimate those equations as probits. Finally, we use ordinary least squares to estimate the share of secured loans made out to SMEs. The results are shown in Table 3: Panel A shows the results for small firm lending, while Panel B presents the results for lending to medium-sized enterprises. At the bottom of each panel we report results testing for differences in the coefficients for foreign versus domestic private banks. Because government-owned banks are the omitted category, differences between this group of banks and foreign and domestic private banks, respectively, can be gleaned from the coefficients on Foreign and Private.

Table 3 shows that when it comes to lending both to small and medium-sized firms, foreign banks are less likely to rate soft information as important and to decentralize loan

\footnotetext{
${ }^{5}$ Mian (2003) notes that government-owned banks are likely to have less rigorous screening and monitoring mechanisms, as evidenced by their higher rates of non-performing loans.

${ }^{6}$ We get similar results if we make the criteria more stringent and define it so that soft information is listed as the top criteria. In fact, in that case, we find that we cannot estimate a coefficient for foreign banks or for developing countries since no foreign bank lists soft information as the top criteria and no bank in developed countries does that either.
} 
Table 2 Number of banks in the sample by country and bank ownership type

\begin{tabular}{lccc}
\hline Countrylownership type & Developed & Developing & Total \\
\hline Foreign & 4 & 38 & 42 \\
Domestic private & 6 & 26 & 32 \\
Government & 1 & 16 & 17 \\
Total & 11 & 80 & 91 \\
\hline
\end{tabular}

approval and risk management processes than domestic private banks. Also, since the coefficients are significantly different, we see that the share of secured lending for foreign banks is higher than that for domestic private banks. Hence, we conclude that foreign banks are more likely to require collateral and attach lower importance to soft information in lending to small and medium-sized firms. On the other hand, we do not find any significant differences across bank types in terms of the use of scoring as a lending technology. Overall, these results confirm that foreign banks are more likely to use arms-length lending technologies and organizational structures in lending to SMEs.

Comparing government-owned to domestic private banks, we find that the former are less likely to rate soft information as important, more likely to decentralize loan approvals for small business lending, and more likely to require collateral when lending to medium-sized firms. Relative to foreign banks, government-owned banks are more likely to decentralize loan approval and risk management of both SME loans. Hence, in general, government-owned banks appear to be more likely to decentralize decisions involving SME finance, but do not appear to rely on relationship lending, since they seem more likely than private banks to use of collateral and hard information in lending to SMEs.

\section{Linking SME finance with lending technologies and organizational structures}

To what extent are differences in lending technologies and organizational structures associated with differences in the extent, type, and pricing of SME loans? While traditionally the literature has claimed that SME lending is largely based on soft information and decentralized organizational structures, studies proposing a new paradigm argue that different lending technologies and organizational structures can be applied to SME finance. In this section, we correlate the proxies for lending techniques and organizational structures, introduced above, with measures of the extent, type, and pricing of SME loans. Given that both aspects of bank business are likely to be determined simultaneously, we refrain from formal regression analysis in this context.

As indicators for SME lending, we use the share of lending to SMEs (expressed as a ratio of total lending), the percentage of SME loan applications approved (i.e., number of applications approved out of total number of SME loan applications received), the share of SME loans devoted to investment, the fees charged on SME loans (as a percentage of the loan amount), and the real interest rate charged on SME loans, both for the best (lowest risk) and for the worst (highest risk) customers. We interpret a higher share of SME loans to total loans and a larger share of SME loan applications approved as indicators of greater interest from banks in lending to SMEs. Given the riskiness associated with making loans to SMEs, SME loans are typically shorter-term than corporate loans to large enterprises, so that we assume that a higher share of (long-term) investment loans indicates a higher level 


\section{a Banks' definition of small enterprises}

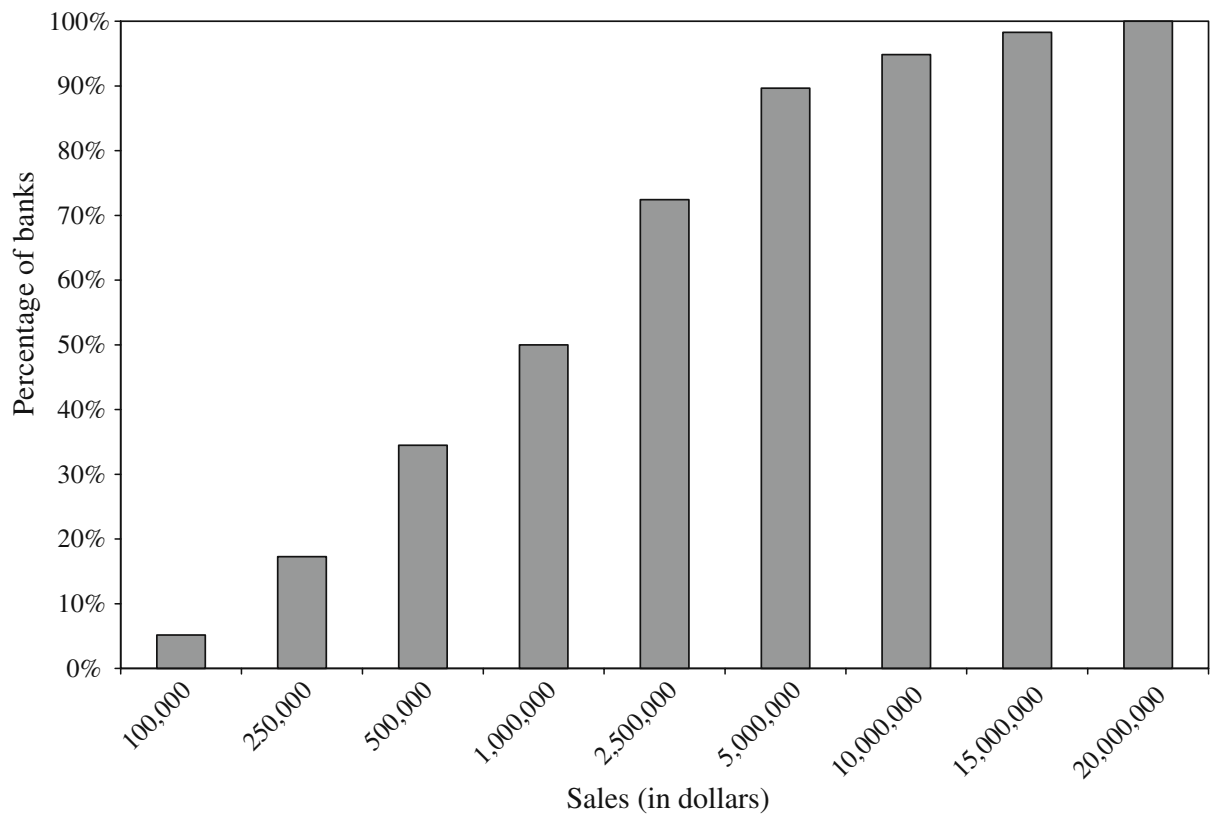

b Banks' definition of medium-sized enterprises

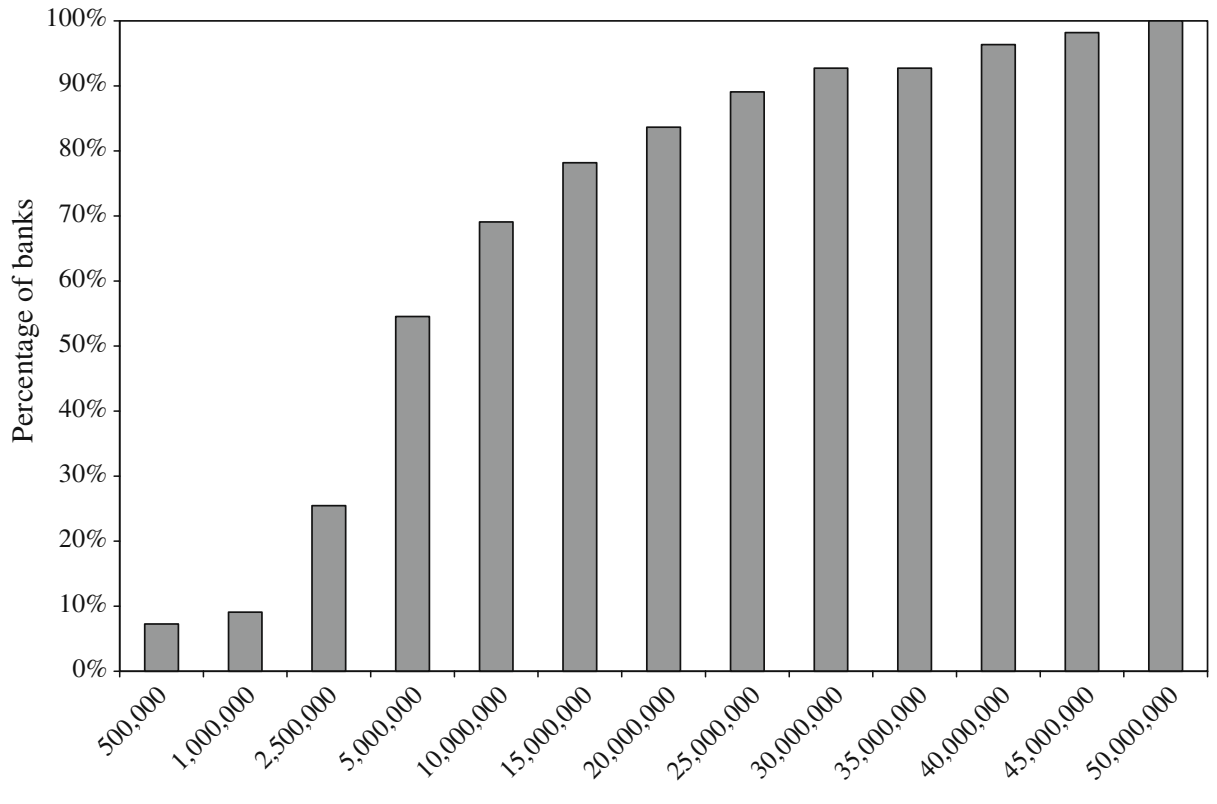

Sales (in dollars)

Fig. 1 a Banks' definition of small enterprises. (\% of banks that define small enterprises as firms with sales less than amount on horizontal axis). b Banks' definition of medium-sized enterprises. (\% of banks that define medium-sized enterprises as firms with sales less than amount on horizontal axis) 
of comfort with lending to the SME segment. Finally, real interest rates and fees are two important indicators of the prices charged to SMEs.

Table 4 presents correlations between different variables capturing the extent, type and pricing of SME lending and variables proxying for lending technologies and organizational structures. Panel A reports correlations for the whole sample, while Panel B reports correlations for banks in developing countries only. The share of loans to SMEs, the share of SME loan applications approved, and the share of SME lending for investment purposes are not significantly correlated with the lending technologies or the organizational structures. We find that loan fees are higher for banks with a higher share of secured lending, but this seems to be driven by banks in developed countries, as the correlation turns insignificant in the sample of banks in developing countries. We also find that real interest rates for SME loans are lower in banks that are more likely to decentralize their loan approval and risk management processes. Finally, we find that the interest rates for the best SME clients are lower in banks that use scoring as part of the loan approval process.

Overall, as predicted by the studies proposing a new paradigm for SME lending, the organizational structures and lending technologies applied to SME finance show limited correlations with the extent, type, or pricing of SME lending. Furthermore, in particular, results do not seem to provide support for the notion that relationship lending is consistently associated with more and cheaper financing for SMEs.

\section{The extent, type, and pricing of SME lending across countries and bank types}

In this final result section, we examine how the extent, type, and pricing of SME lending varies by bank ownership type. On the one hand, some country case studies suggest that foreign banks are less likely to engage in SME lending because they tend to adopt armslength lending technologies and have centralized and hierarchical organizational structures (e.g., see Mian 2006; Gormley 2010; Sengupta 2007). On the other hand, recent studies proposing a new paradigm for SME finance take a more nuanced view arguing that foreign banks can be as engaged in lending to SMEs, while at the same time acknowledging differences in lending technologies and organizational structures between foreign and domestic private banks (see Berger and Udell 2006 and de la Torre et al. 2010). ${ }^{7}$

When it comes to government-owned banks, the existing bank-level evidence suggests that, while government-owned banks tend to charge lower rates than domestic private banks, they are more likely to lend to large firms and to lend for political motives (see Sapienza 2004; Berger et al. 2008; Cole 2009). Furthermore, some studies have found that less SME credit is available in nations with large market shares of government-owned banks (e.g., Beck et al. 2004; Berger et al. 2004) and large shares of government bank ownership are typically associated with unfavorable macroeconomic consequences and less developed financial and economic systems (e.g., La Porta et al. 2002; Barth et al. 2004; Berger et al. 2004).

In this section, we also explore differences in the extent, type and pricing of SME finance across countries. The literature on private credit depth suggests that lending will be affected by the institutional and legal environment in the country (see Djankov et al. 2007). Furthermore, studies using firm-level data show that these factors disproportionally affect

\footnotetext{
${ }_{7}^{7}$ Firm-level evidence also shows that SME access to finance improves with greater foreign bank entry (see Clarke et al. 2006 and Giannetti and Ongena 2009).
} 
Table 3 Lending technologies and organizational structures across bank ownership types. Table shows results from regressing variables proxying for the lending technologies and organizational structures used for SME financing on: a dummy for developing countries, a dummy for foreign banks, and a dummy for domestic private banks. Government-owned banks are the omitted category. Use of scoring takes the value of 1 if scoring is used by the bank in making lending decisions and 0 otherwise. Importance of soft information equals 1 if the bank rates "soft" information (captured by firm owner characteristics) among the top two factors that the bank considers in making SME financing decisions and 0 otherwise. Share of SME loans secured is the percentage of SME loans that is collateralized. Decentralization of loan approval takes the value of 1 if lending decisions are made only or primarily at bank branches and 0 otherwise. Decentralization of risk management takes the value 1 if all risk management decisions are made only or primarily at bank branches and 0 otherwise. Regressions for the use of scoring, importance of soft information, and the extent of decentralization are estimated as probits. We use ordinary least squares to estimate the share of secured loans made out to SMEs. Robust $\mathrm{z} / \mathrm{t}$ statistics are in brackets

Use of Importance of Share of loans Decentralization Decentralization scoring soft information secured (\%) of loan approvals of risk management

Panel A: Small firm financing

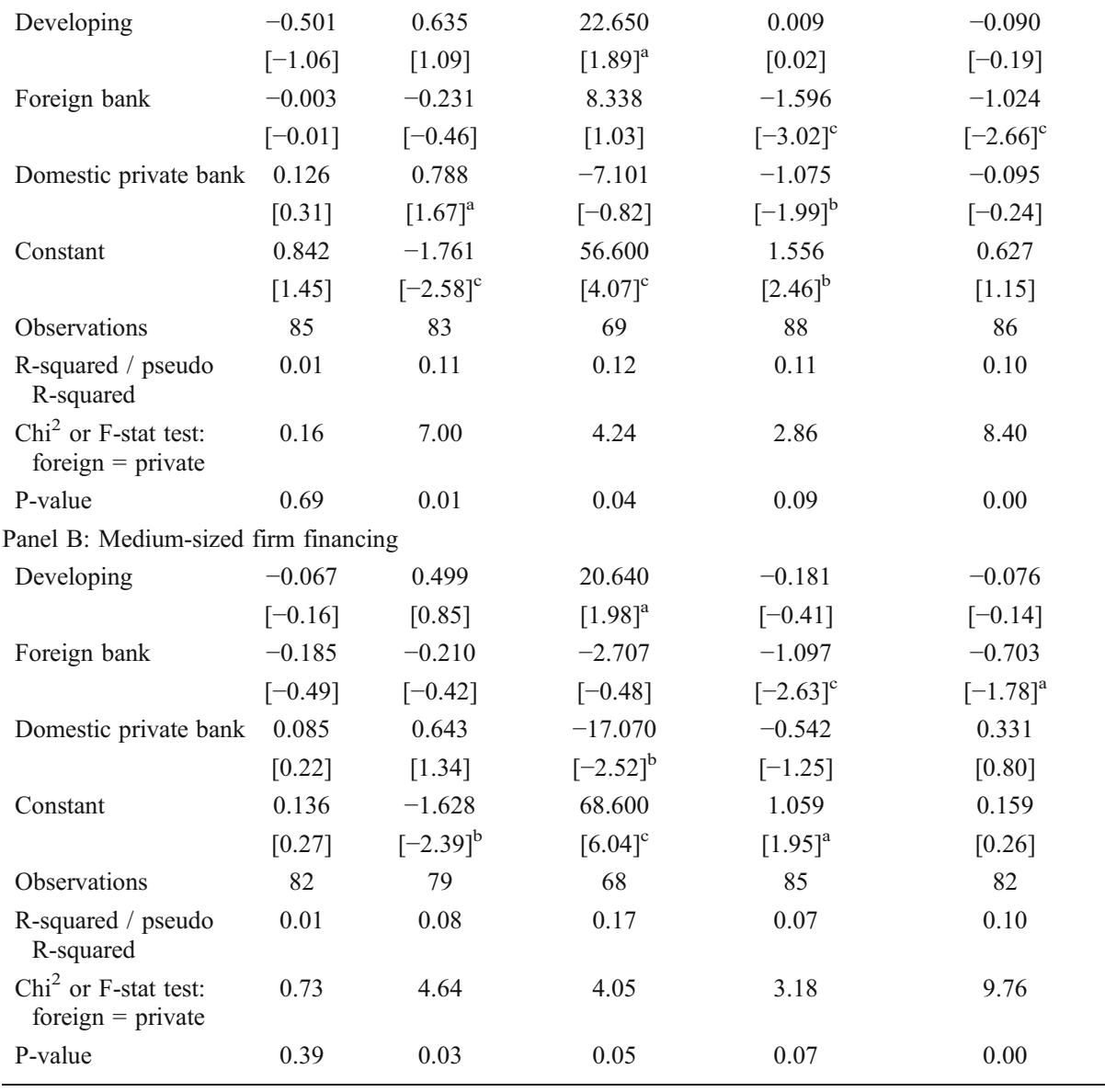

a,b,c denotes significance at $10 \%, 5 \%$, and $1 \%$ significance levels, respectively 


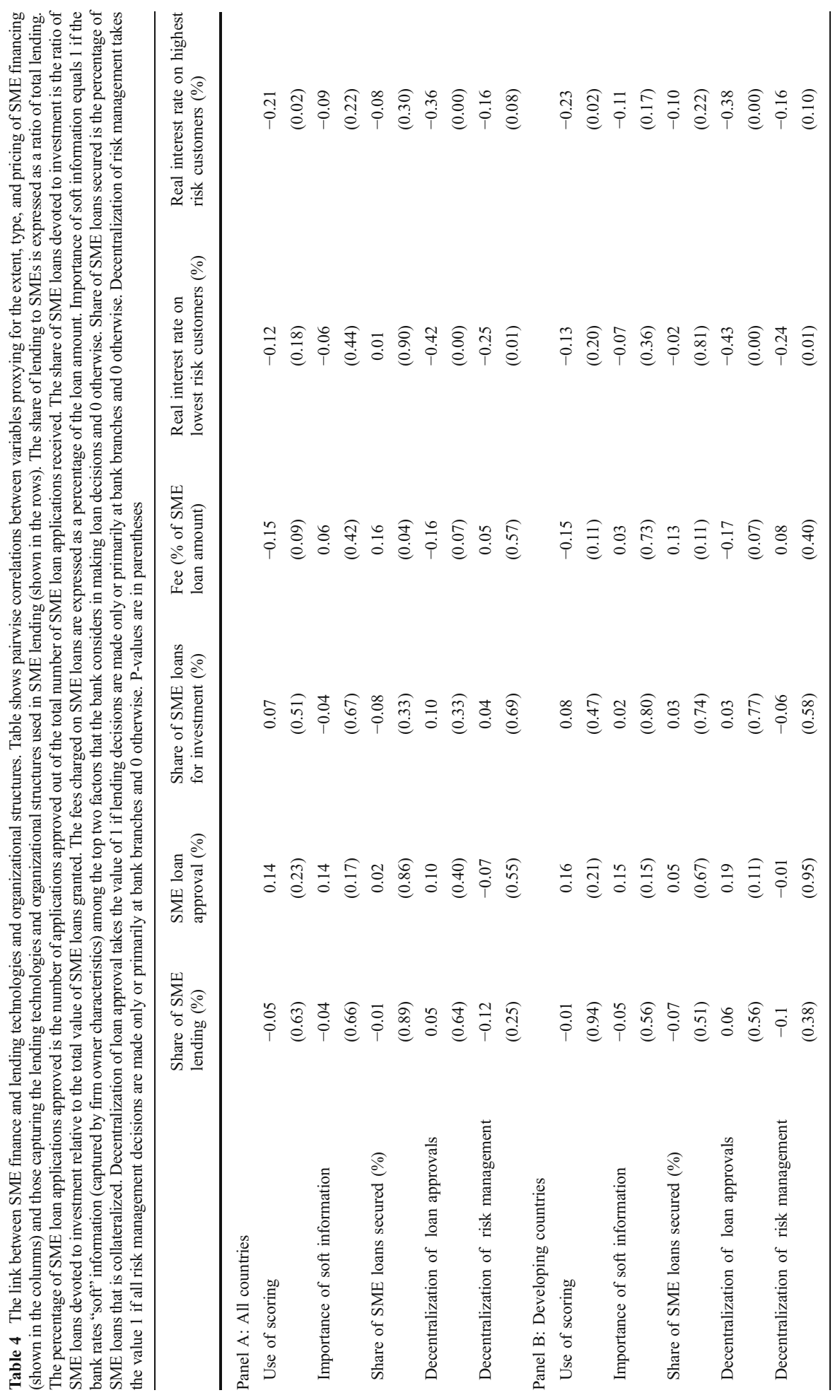


SMEs' access to external financing and growth (see Beck et al. 2005, 2006, 2008a). Here, we use supply-side data to shed further light on this question.

To examine the differences in the extent, type and pricing of SME finance across banks and countries we estimate the following regression models:

$$
\begin{gathered}
Y_{i}=\beta_{0}+\beta_{1} \text { Foreign }_{i}+\beta_{2} \text { Private }_{i}+\beta_{3} \text { Dev }_{i}+e_{i} \\
\text { Ssub }_{i}=\delta_{0}+\delta_{1} \text { Foreign }_{i}+\delta_{2} \text { Private }_{i}+\delta_{3} \text { Dev }_{i}+\delta_{4 i} X_{i}+e_{i}
\end{gathered}
$$

where i refers to the bank. $Y$ stands, alternatively, for the share of lending to SMEs (out of total lending), the percentage of SME loan applications approved, the share of SME loans devoted to investment, the fees charged on SME loans (as a percentage of the loan amount), and the interest rate charged on SME loans, both for the best and for the worst customers. $Y s u b$ refers to the subset of variables in $Y$ for which we observe that $D e v$, the dummy for developing countries is significant. Foreign and Private are defined as before. $X$ refers to different measures of the institutional and legal environment. While Eq. 2 is intended to examine differences in SME finance across bank ownership and country types, in Eq. 3 we try to examine what aspects of the institutional and legal environment explain the crosscountry differences we identify in (2). We estimate a tobit regression model for the share SME loans devoted to investment and conduct ordinary least squares estimations for all other dependent variables.

The results from estimating Eq. 2 are shown in Table 5. Panel A shows results for small firm financing and Panel B shows results for medium-sized firm lending. The table indicates that controlling for country type (i.e., distinguishing between developed and developing countries), there are few significant differences in the extent, type, and pricing of SME lending across bank ownership types. Most notably, we find no evidence that foreign banks tend to lend less to SMEs than other banks. In fact, if we focus only on developing countries (see Appendix Table 8), we find that foreign banks are more likely to approve loans to small firms than domestic private banks and do so at fees and rates that are not significantly different than those charged by domestic private banks. These results are in line with studies that discuss a new paradigm in SME lending, where different bank types are able to serve SMEs using different lending technologies (see Berger and Udell 2006; and de la Torre et al. 2010). Relative to government-owned banks, domestic private banks seem to charge higher interest rates for lending to both small and medium-sized enterprises and foreign banks seem to charge higher fees to small enterprises.

Controlling for bank ownership types, Table 5 reveals statistically and economically significant differences in the type and pricing of SME finance across banks operating in developing versus developed countries. In particular, we find that the share of SME lending devoted to investments (i.e., long-run lending) is statistically and economically significantly lower (32 and 25 percentage points lower for small and medium-sized enterprises, respectively) among banks in developing countries. At the same time, banks in developing countries charge $0.8(0.7)$ percentage point higher fees for small (mediumsized) enterprises and three percentage points higher interest rates for small enterprises than those in developed countries. On the other hand, there are no statistically significant differences in the share of loans to SMEs or in the percentage of SME applications approved.

Tables 6 and 7 examine whether different features of the legal, and institutional environment across countries can explain the differences in the type and pricing of SME 
lending across developing and developed countries that we report in Table 5. In particular, in Tables 6 and 7 we repeat the estimations where the dummy for developing countries was significant in Table 5, while adding variables that capture: the cost of enforcing contracts (expressed as a percentage of the value of the claims), the cost of registering property (expressed as a percentage of the value of the property) that can be used as loan collateral, the availability of credit history information (expressed as an index between 0 and 6, with higher numbers meaning that credit history information is richer and more widely available in a country), and the degree of protection of property rights. The first three variables come from the World Bank Doing Business Indicators Database. ${ }^{8}$ The measure of property rights is part of the Index of Economic Freedom reported by the Heritage Foundation. Property rights protection is an index between 0 and 100, with higher numbers indicating greater protection of property rights.

The results in Tables 6 and 7 show that the lower share of SME loans for investment observed for developing countries seems to be explained by a higher cost of registering property in these countries, since once we control for this variable, the developing country dummy is no longer significant both in the regressions pertaining to small and mediumsized firm financing. At the same time, the higher fees observed in developing countries for small and medium-sized firm financing seem related to the higher cost of property registration and worse credit information environment in developing countries. Also, the fact that developing countries rank below developed countries in property right protection seems to matter in explaining differences in fees when it comes to financing medium-sized firms. Finally, the higher interest rates observed in developing countries for small firm financing seem to be associated with the higher costs of enforcing contracts and worse protection of property rights prevalent in developing countries.

\section{Conclusions}

This paper used data from a survey of large banks around the world to study how SME financing by large banks differs across countries and bank ownership types and to investigate the link between lending technologies/organizational structures and SME finance. In particular, this is the first study to empirically test the new paradigm in SME lending first proposed by Berger and Udell (2006), which suggests that SME lending is not dependent on relationship lending.

Our data yield a number of interesting findings. First, different banks apply different lending technologies and organizational structures. In particular, foreign banks are more likely to use arms-length lending technologies and centralized organizational structures. Second, we do not find a strong link between lending technologies and organizational structures, on the one hand, and the extent, type, and pricing of lending to SMEs on the other hand. Third, even though we find differences in the lending technologies and organizational structures used across bank ownership types, we find few significant differences across bank types in the extent, type and pricing of SME finance. Overall, we find that the link between lending technologies, organizational structures, and SME lending is not consistent with the notion that SME finance is based on relationship lending, a type of financing rooted in the use of soft information and decentralized organizational structures. Finally, we find differences in the extent, type and pricing of SME loans across countries, which appear to be driven by differences in the institutional and legal environment. Going forward, it would be interesting to expand the

\footnotetext{
$\overline{{ }^{8} \text { See http://www.doingbusiness.org. }}$
} 


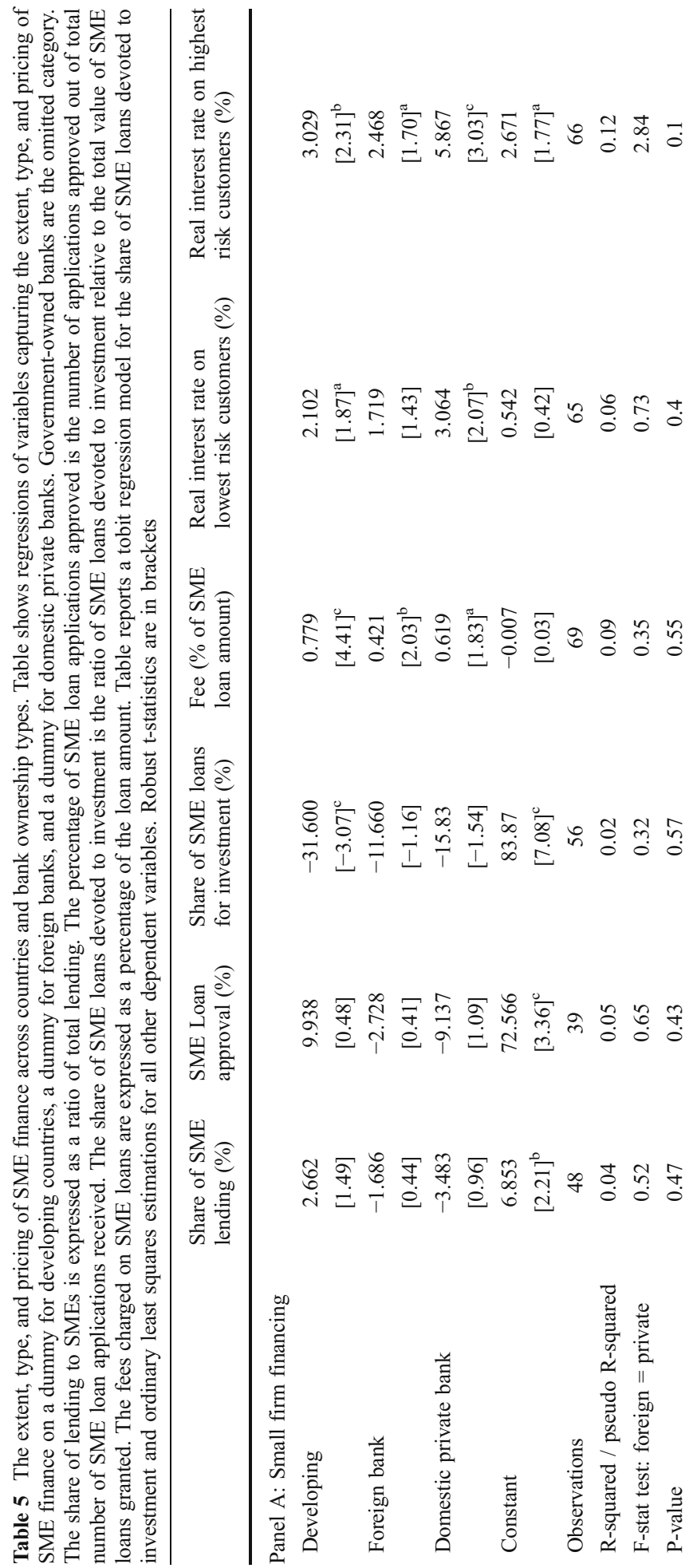




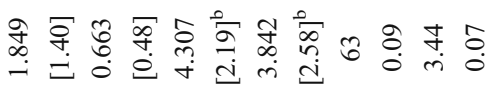

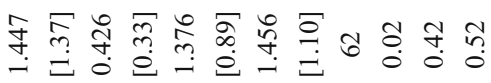

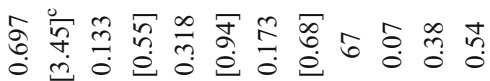

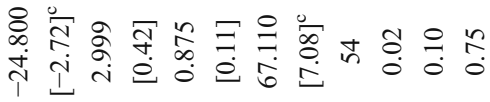

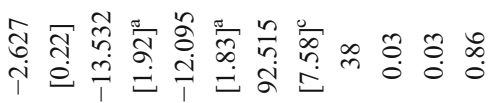

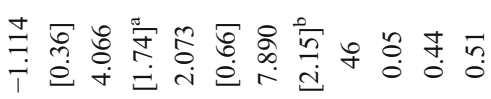

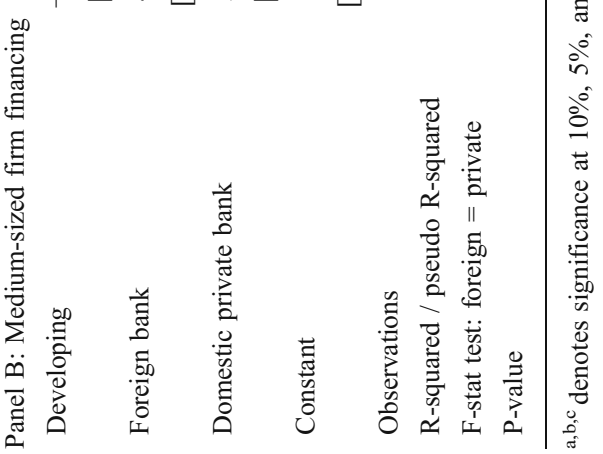




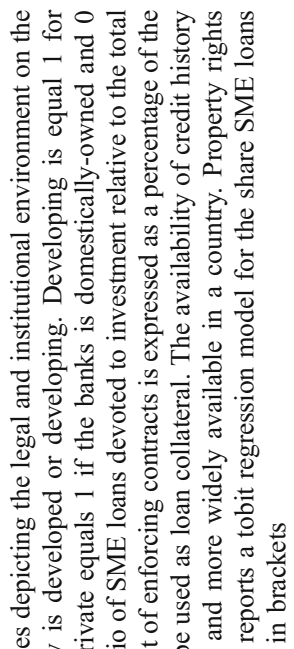
ช.

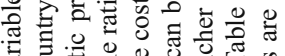

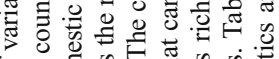

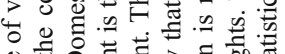

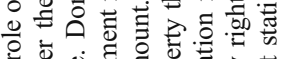

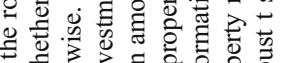

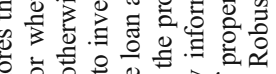

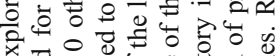

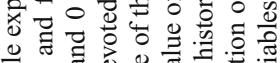

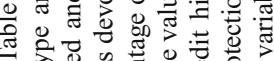

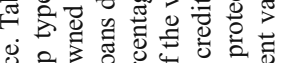

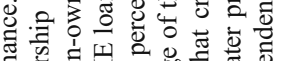

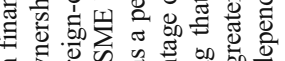
घ

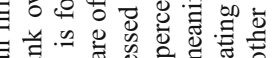

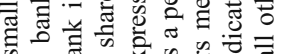

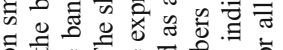
¿

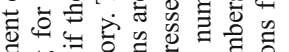

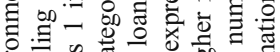

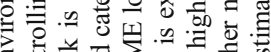

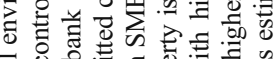

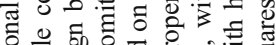

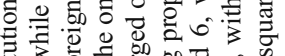

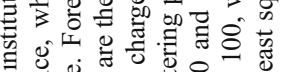

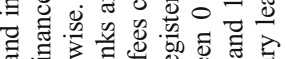

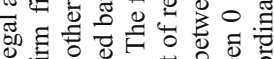

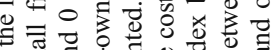

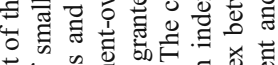
氙

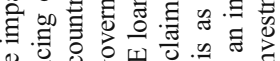

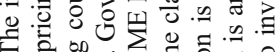

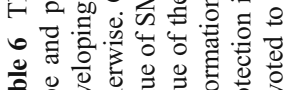

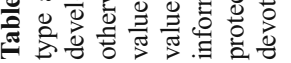

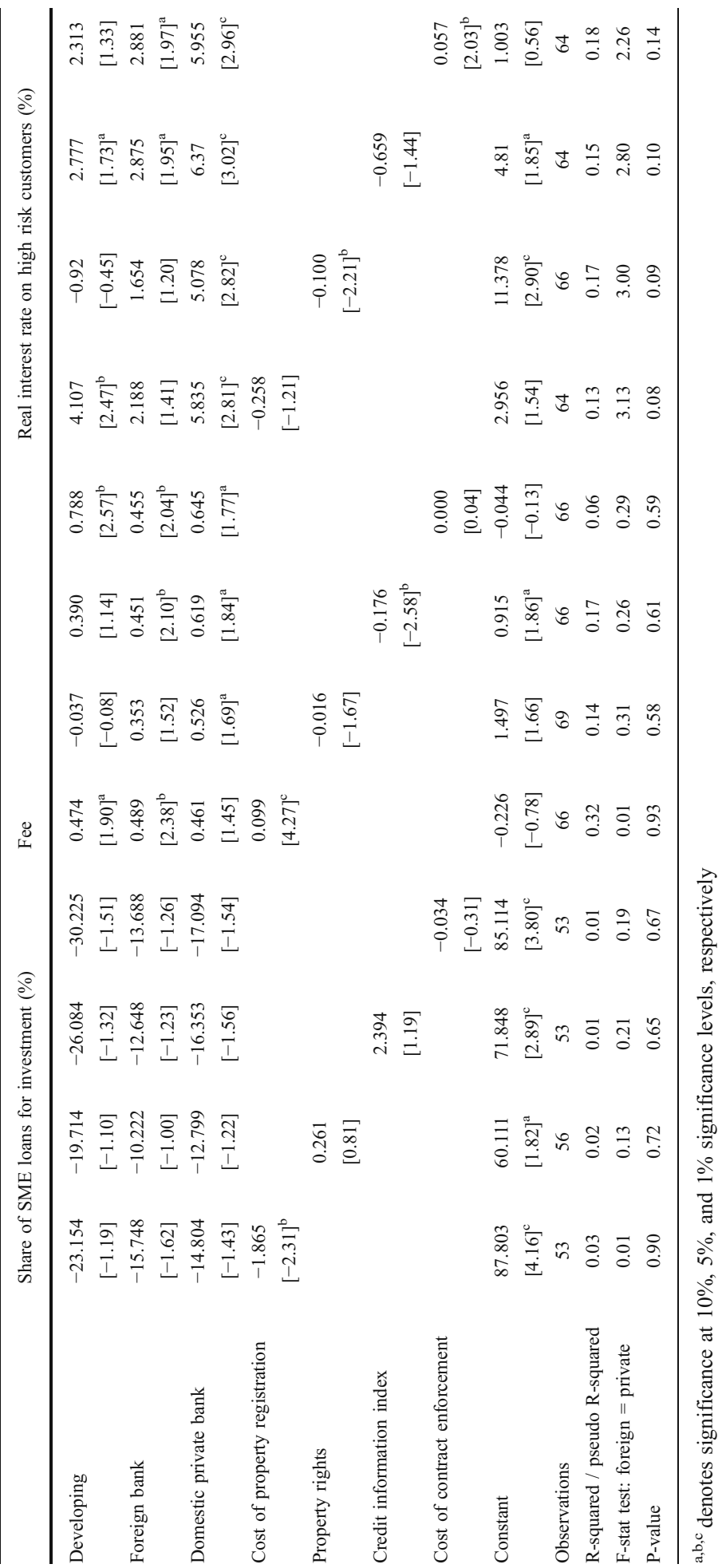




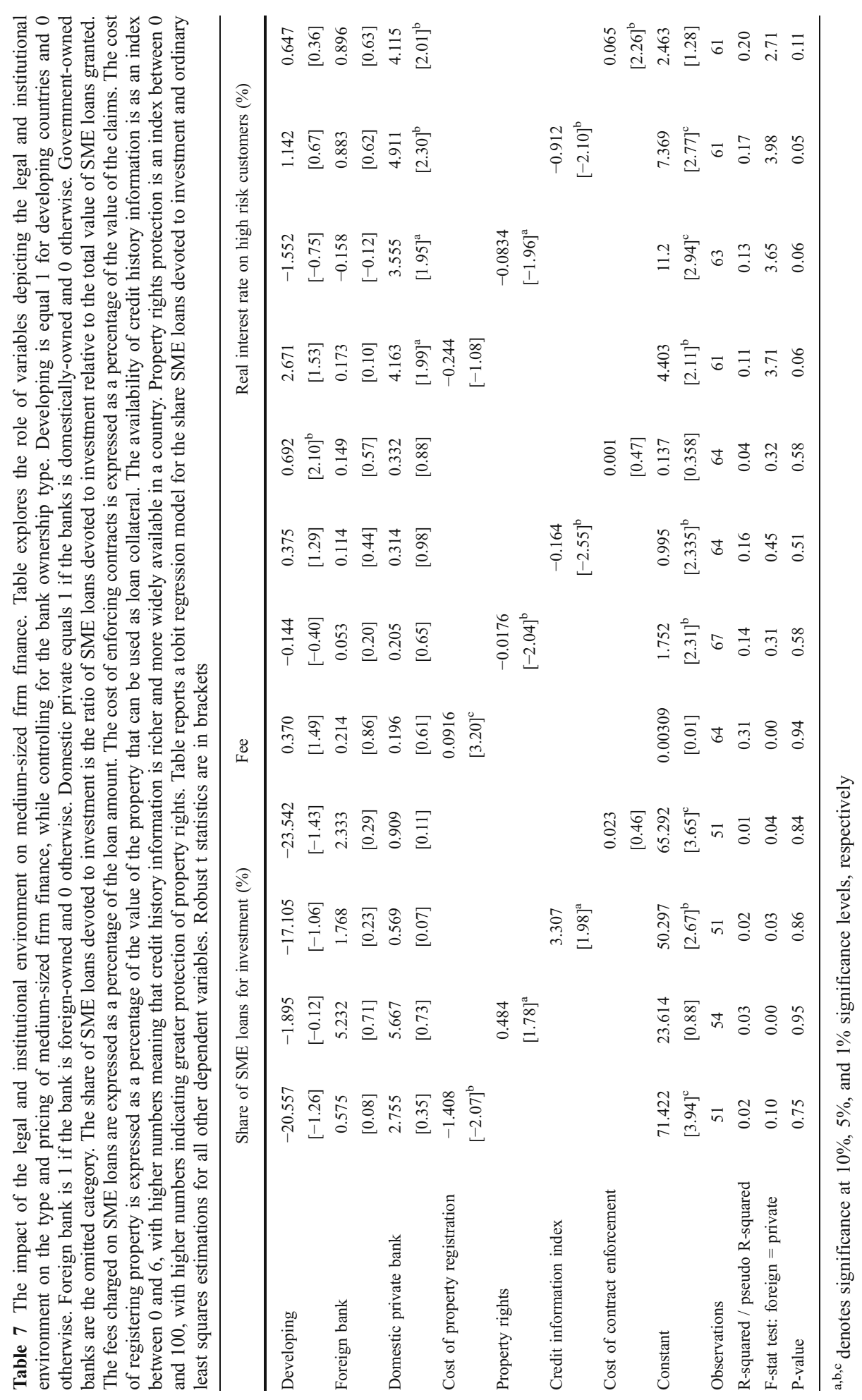


number of banks and countries surveyed in order to see if we can corroborate our findings in a larger sample, especially one that includes small as well as large banks.

Acknowledgements We would like to thank Diego Anzoategui, Subika Farazi, and Noemi Soledad Lopez for outstanding research assistance. We are also very grateful to Bob DeYoung (the editor), an anonymous referee, Ricardo Bebczuk, and participants at the World Bank Small Business Finance conference for useful comments and suggestions. The views expressed in this paper are solely those of the authors and do not represent the opinions of The World Bank, its Executive Directors or the countries they represent.

Open Access This article is distributed under the terms of the Creative Commons Attribution Noncommercial License which permits any noncommercial use, distribution, and reproduction in any medium, provided the original author(s) and source are credited.

\section{Appendix}

Table 8 The extent, type, and pricing of SME finance across bank ownership types in developing countries. Table shows regressions of variables capturing the extent, type and pricing of SME finance on a dummy for foreign banks and a dummy for domestic private banks. Government-owned banks are the omitted category. The share of lending to SMEs is expressed as a ratio of total lending. The percentage of SME loan applications approved is the number of applications approved out of the total number of SME loan applications received. The share of SME loans devoted to investment is the ratio of SME loans devoted to investment relative to the total value of SME loans granted. The fees charged on SME loans are expressed as a percentage of the loan amount. Table reports a tobit regression model for the share SME loans devoted to investment and ordinary least squares estimations for all other dependent variables. Robust $t$ statistics are in brackets

\begin{tabular}{|c|c|c|c|c|c|c|}
\hline & $\begin{array}{l}\text { Share of } \\
\text { SME lending } \\
(\%)\end{array}$ & $\begin{array}{l}\text { SME loan } \\
\text { approval } \\
(\%)\end{array}$ & $\begin{array}{l}\text { Share of SME } \\
\text { loans for } \\
\text { investment } \\
(\%)\end{array}$ & $\begin{array}{l}\text { Fee ( } \% \text { of } \\
\text { SME loan } \\
\text { amount) }\end{array}$ & $\begin{array}{l}\text { Real interest } \\
\text { rate on lowest } \\
\text { risk customers } \\
(\%)\end{array}$ & $\begin{array}{l}\text { Real interest } \\
\text { rate on highest } \\
\text { risk customers } \\
(\%)\end{array}$ \\
\hline \multicolumn{7}{|l|}{ Panel A: Small firm financing } \\
\hline \multirow[t]{2}{*}{ Foreign bank } & -1.388 & 1.562 & -13.568 & 0.456 & 2.020 & 2.903 \\
\hline & {$[0.34]$} & {$[0.25]$} & {$[-1.23]$} & {$[2.04]^{\mathrm{b}}$} & {$[1.58]$} & {$[1.87]^{\mathrm{a}}$} \\
\hline \multirow[t]{2}{*}{ Domestic private bank } & -3.320 & -13.427 & -17.062 & 0.643 & 3.486 & 6.046 \\
\hline & {$[0.80]$} & {$[1.64]$} & {$[-1.53]$} & {$[1.75]^{\mathrm{a}}$} & {$[2.11]^{\mathrm{b}}$} & {$[2.78]^{\mathrm{c}}$} \\
\hline \multirow[t]{2}{*}{ Constant } & 9.32 & 82.504 & 53.592 & 0.747 & 2.356 & 5.431 \\
\hline & {$[2.56]^{\mathrm{b}}$} & {$[15.42]^{\mathrm{c}}$} & {$[5.56]^{\mathrm{c}}$} & {$[4.66]^{\mathrm{c}}$} & {$[3.12]^{\mathrm{c}}$} & {$[5.70]^{\mathrm{c}}$} \\
\hline Observations & 42 & 35 & 50 & 63 & 57 & 58 \\
\hline R-squared / pseudo R-squared & 0.02 & 0.15 & 0.01 & 0.05 & 0.05 & 0.10 \\
\hline F-stat test: foreign $=$ private & 0.49 & 4.71 & 0.20 & 0.26 & 0.67 & 1.86 \\
\hline P-value & 0.49 & 0.04 & 0.66 & 0.61 & 0.42 & 0.18 \\
\hline \multicolumn{7}{|c|}{ Panel B: Medium-sized firm financing } \\
\hline \multirow[t]{2}{*}{ Foreign bank } & 5.175 & -14.072 & 2.236 & 0.150 & 0.735 & 0.909 \\
\hline & {$[2.29]^{\mathrm{b}}$} & {$[1.96]^{\mathrm{a}}$} & {$[0.28]$} & {$[0.57]$} & {$[0.53]$} & {$[0.61]$} \\
\hline \multirow[t]{2}{*}{ Domestic private bank } & 4.689 & -11.556 & 0.855 & 0.324 & 1.667 & 4.441 \\
\hline & [1.43] & {$[1.72]^{\mathrm{a}}$} & {$[0.10]$} & {$[0.85]$} & {$[0.96]$} & {$[1.99]^{\mathrm{a}}$} \\
\hline \multirow[t]{2}{*}{ Constant } & 5.625 & 89.888 & 42.7 & 0.860 & 2.657 & 5.528 \\
\hline & {$[3.78]^{\mathrm{c}}$} & {$[25.60]^{\mathrm{c}}$} & {$[6.51]^{\mathrm{c}}$} & {$[3.85]^{\mathrm{c}}$} & {$[2.60]^{\mathrm{b}}$} & {$[5.39]^{\mathrm{c}}$} \\
\hline Observations & 40 & 34 & 47 & 59 & 54 & 55 \\
\hline R-squared / pseudo R-squared & 0.07 & 0.04 & 0.00 & 0.01 & 0.01 & 0.08 \\
\hline F-stat test: foreign $=$ private & 0.02 & 0.09 & 0.04 & 0.26 & 0.3 & 2.43 \\
\hline P-value & 0.89 & 0.77 & 0.85 & 0.61 & 0.58 & 0.13 \\
\hline
\end{tabular}

a,b,c denotes significance at $10 \%, 5 \%$, and $1 \%$ significance levels, respectively 


\section{References}

Ayyagari M, Beck T, Demirgüç-Kunt A (2007) Small and medium enterprises across the globe. Small Bus Econ 29:415-434

Barth JR, Caprio G Jr, Levine R (2004) Bank supervision and regulation: what works best? J Financ Intermed 13:205-248

Beck T, Demirguc-Kunt A, Maksimovic V (2004) Bank competition and access to finance: international evidence. J Money Credit Bank 36:627-648

Beck T, Demirgüç-Kunt A, Maksimovic V (2005) Financial and legal constraints to firm growth: does firm size matter? J Finance 60:137-177

Beck T, Demirgüç-Kunt A, Laeven L, Maksimovic V (2006) The determinants of financing obstacles. J Int Money Financ 25:932-952

Beck T, Demirgüç-Kunt A, Maksimovic V (2008a) Financing patterns around the world: are small firms different? J Financ Econ 89:467-487

Beck T, Demirgüç-Kunt A, Martinez Peria M (2008b) Bank financing for SMEs around the world: drivers, obstacles, business models, and lending practices. World Bank Policy Research Working Paper 4785

Berger A, Udell G (1996) Universal banking and the future of small business lending. In: Saunders A, Walter I (eds) Financial system design: the case for universal banking. Irwin (Richard D), Burr Ridge, pp 559-627

Berger A, Udell G (2006) A more complete conceptual framework for SME finance. J Bank Finance 30:2945-2966

Berger A, Kayshap A, Scalise J (1995) The transformation of the U.S. banking industry: what a long strange trip it's been. Brookings Paper Econ Activ 2:155-219

Berger A, Klapper L, Udell G (2001) The ability of banks to lend to informationally opaque small businesses. J Bank Finance 25:2127-2167

Berger A, Hasan I, Klapper L (2004) Further evidence on the link between finance and growth: an international analysis of community banking and economic performance. J Financ Serv Res 25:169-202

Berger A, Rosen R, Udell G (2007) Does market size structure affect competition? The case of small business lending. J Bank Finance 31:11-33

Berger A, Klapper L, Martinez Peria M, Zaidi R (2008) Bank ownership type and banking relationships. J Financ Intermed 17(1):37-62

Canales R, Nanda R (2008) Bank structure and the terms of lending to small businesses. Harvard Business School, mimeo

Clarke G, Cull R, Martinez Peria M (2006) Foreign bank participation and access to credit across firms in developing countries. J Comp Econ 34:774-795

Cole S (2009) Fixing market failures or fixing elections? Agricultural credit in India. American Economic Journal: Applied Economics 1:219-250

De la Torre A, Martinez Peria M, Schmukler S (2010) Bank involvement with SMEs: beyond relationship lending. J Bank Financ, forthcoming.

Djankov S, McLiesh C, Shleifer A (2007) Private credit in 129 countries. J Financ Econ 84:299-329

Giannetti M, Ongena S (2009) Financial integration and entrepreneurial activity: evidence from foreign bank entry in emerging markets. Rev Finance 13:181-223

Gormley TA (2010) The impact of foreign bank entry in emerging markets: evidence from India. J Financ Intermed 19(1):26-51

IADB (2004) Unlocking credit: the quest for deep and stable lending. The Johns Hopkins University Press

Keeton W (1995) Multi-office bank lending to small businesses: some new evidence. Fed Reserve Bank Kansas City Econ Rev 80:45-57

La Porta R, Lopez-de-Silanes F, Shleifer A (2002) Government ownership of commercial banks. J Finance 57(1):265-301

Liberti JM, Mian A (2009) Estimating the effect of hierarchies on information use. Rev Financ Stud 22 (10):4057-4090

Mian A (2003) Foreign, private domestic, and government banks: new evidence from emerging markets. University of Chicago, mimeo

Mian A (2006) Distance constraints: the limits of foreign lending in poor economies. J Finance 61(3):14651505

Sapienza P (2004) The effects of government ownership on bank lending. J Financ Econ 72(2):357-384

Schiffer M, Weder B (2001) Firm size and the business environment: worldwide survey results. International Finance Corporation Discussion Paper 43

Sengupta R (2007) Foreign entry and bank competition. J Financ Econ 84(2):502-528

Stein J (2002) Information production and capital allocation: decentralized vs. hierarchical firms. J Finance 57:1891-1921 
Stephanou C, Rodriguez C (2008) Bank financing to small- and medium-sized enterprises (SMEs) in Colombia. World Bank Policy Research Working Paper 4481

Strahan P, Weston J (1996) Small business lending and bank consolidation: is there cause for concern? Current Issues in Economics and Finance, Federal Reserve Bank of New York 2:1-6

World Bank (2007a) Bank financing to small and medium enterprises: survey results from Argentina and Chile. Mimeo

World Bank (2007b) Bank lending to small and medium enterprises: The Republic of Serbia. Mimeo 